\title{
SCREENING SPONGES FOR BACTERIOCIDE TO BE USED IN SHRIMP CULTURE
}

\author{
Taufik Ahmad"), Emma Suryati ${ }^{*}$ and Muliani ${ }^{*}$
}

\begin{abstract}
Sponges are suspected of having potential for producing bioactive material that can be used for various purposes. The experiment aimed at identifying sponges which could produce bioactive materials for fish health management purposes. The screening of bioactive extracts from 25 species of sponge was conducted by bioassay test using bacteria such as Vibrio spp., Aeromonas spp., Pseudomonas spp., Acinetobacter spp., and Enterobacteriaceae as bioindicators. Fractionation using different solvents i.e., hexane, acid ethyl acetate, natural ethyl acetate, and water was carried out to obtain isolates of bioactive substant. Based on screening results, 1. bioactive extract from Halichondria cartilagena inhibits the growth of Vibrio spp., 2. bioactive extract from Callyspongia pseudoreticulata prove to be a good inhibitor for Aeromonas spp., Enterobacteraceae, and Pseudomonas spp., 3. bioactive extract from Auletta spp. inhibited the growth of Acinetobacter spp., 4. the active fraction extracted from $H$. cartilagena and Auletta spp. was polar bioactive 5., from C. pseudoreticulata, the active fraction toward Pseudomonas spp. was acid ethyl acetate semipolar bioactive and toward Enterobacteriaceae and Aeromonas spp. was natural ethyl acetate semipolar bioactive. Bioactive isolates extracted from sponges could be promising for bacteriocides, especially in fish culture.
\end{abstract}

KEYWORDS: Sponges, bioactive, bacteriocide, shrimp culture

\section{Introduction}

Sponges are one of the biological components of coral reefs. Several sponges have been reported to contain bioactive substances which can be used for medical and pharmaceutical purposes. Among them are Hyatella intestinalis (Karuso et al. 1989), Algillus flabelliformis (Gunasekara et al. 1989), Hippospongia comunnis, Spongia officinalis, Ircinia virabilis, Spongia gracillis (Madaio et al. 1989), Dysidea avara (Crispino et al. 1989), Erylus lendenfeldi. Dyctionella incisa (Cimminielo et al. 1989). It seems that sponges have potential for producing bacteriocides which can be applied to different purposes, including shrimp and fish culture.

") Researchers at Research Intitute for Coastal Fisheries, Maros 
Expansion of fish and shrimp culture brings increase attention to problems caused by diseases. Vibrio harveyi and Vibrio alginoliticus, Aeromonas spp., Pseudomonas spp., and Enterobacteriacea are among the bacteria causing mass mortality of cultured shrimp (Atmomarsono et al. 1994; Madeali et al. 1994). Rukyani (1994) reported that bacteria caused shrimp cultured losses worth more than US $\$ 500$ million in 1993 . To overcome further mass mortality, most of the shrimp farmers applied antibiotics such as chloram-phenicol, oxytetracyclin, and prefuran (Brown 1989). Unfortunatelly, the use of antibiotics has been proven to be ineffective and may create problems through stimulating development of immunity to the pathogens.

Realising the harm of using antibiotik, Hadiman (1982) and Suryati (1993) used active ingredients of some fruits and plants to eradicate pathogens from shrimp ponds. However the toxicity of such ingredients is distinctively affected by water salinity and temperature. Acumulation of organic matter in cultures may also cause problems. Since sponges is originated from the sea and share the same ecosystem with shrimp, the bioactive extract may be assumed to have active ingredients which could be used as bacteriocides and would not harm the environment. This research aims at finding the sponges which have the potential to produce bacteriocides.

\section{Material and Methods}

The sponges were collected from Spermonde (South Sulawesi) coastal waters. The fresh samples were submerged in organic solvents and kept at $18^{\circ} \mathrm{C}$. The identification of genus and species was based on morphological characteristic (Barnes 1990; Brusca 1990) and carried out at Research Institute for Coastal Fisheries laboratory. Masceration in methanol was applied for 72 hours to obtain $600 \mathrm{ml}$ crude extracts from $200 \mathrm{~g}$ of blended sponge which then be evaporated to $200 \mathrm{ml}$.

Fractionation of the samples was carried out using different solvents recomended by Harborne (1973) as shown in Figure 1. The bioindicators used for bioactive screening were Vibrio spp., Aeromonas spp., Pseudomonas spp., Acinetobacter spp., and Enterobacteriaceae which were isolated from diseased shrimp. Bioassay testing of crude extract and of each fraction was carried out using the agar diffusion method as modified by Cowan (1985).

\section{Results and Discussion}

Among 25 crude extracts of sponges tested toward Enterobacteriaceae, Vibrio spp., Aeromonas spp., and Acinetobacter spp. Crude extracts of 3 species have been proved to be good inhibitors for all of the bioindicators. Extracts 


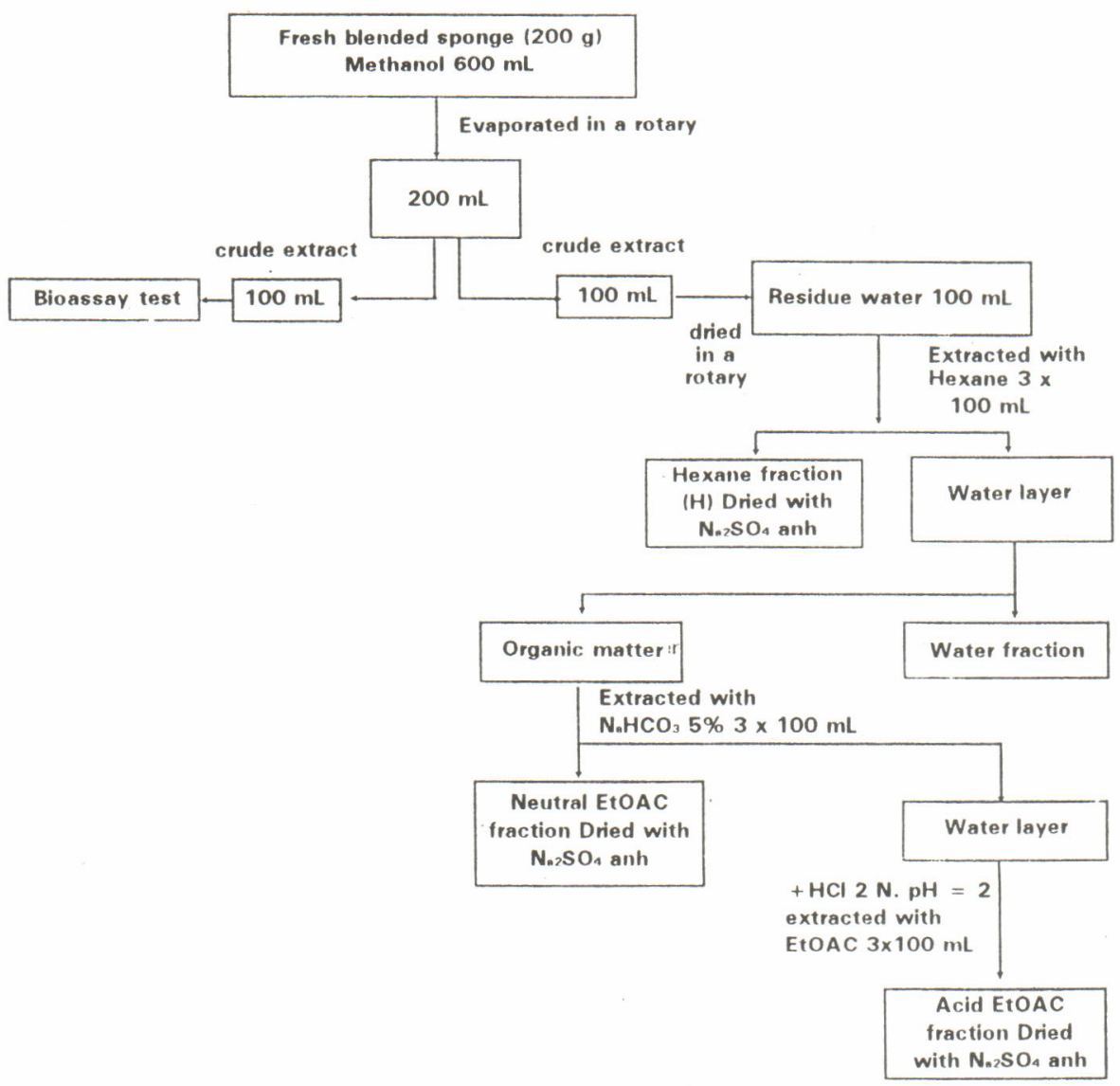

Figure 1. The fractionation flow of sponges bioactive

from 2 species could inhibit the growth of Acinetobacter spp., and extracts from Enterobacteriaceae and 1 species could only inhibit the growth of Enterobacteriaceae. Besides, extracts from 10 species inhibited growth of Vibrio spp., 9 species inhibit Aeromonas spp., and 2 species inhibit Enterobacteriaceae but in a weaker resistance compared to the other 5 species (Table 1). There were 8 species that did not produce extracts which could restrain the growth of bioindicators used.

The differences between biological and chemical characteristics of bioindicators produce different inhibition capabilities for the crude extracts from sponges. Crude extract of $H$. cartilagena (Figure 2) is highly capable of 
Abmad, T.; Suryati, E. and Muliani

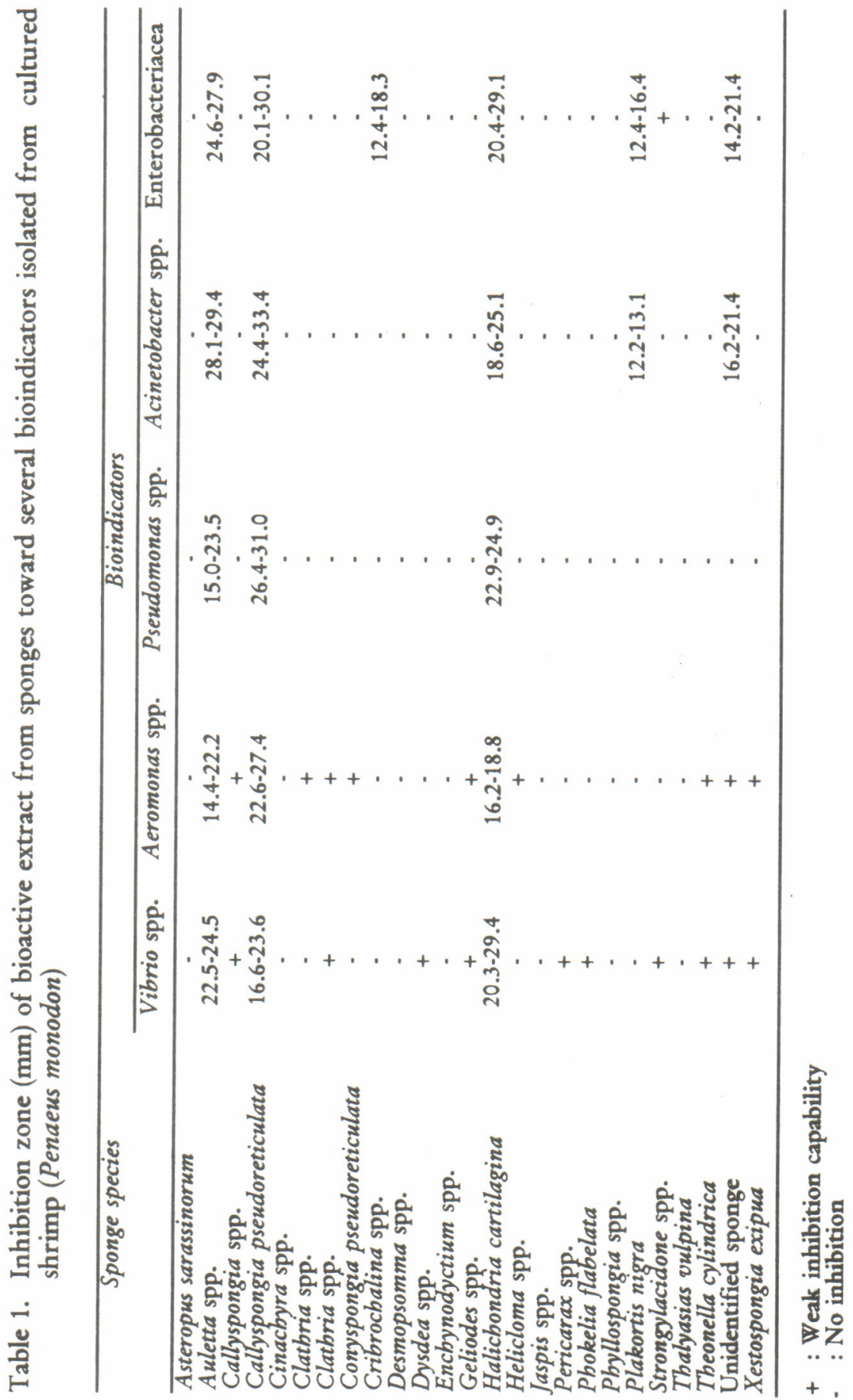


inhibiting the growth of Vibrio spp. C. pseudoreticulata (Figure 3) produces a bioactive material substances which is strongly inhibits growth of Aeromonas spp., Pseudomonas spp., and Enterobacteriaceae. Crude extract of Auletta spp. (Figure 4) actively restrains the growth of Acinetobacter spp.

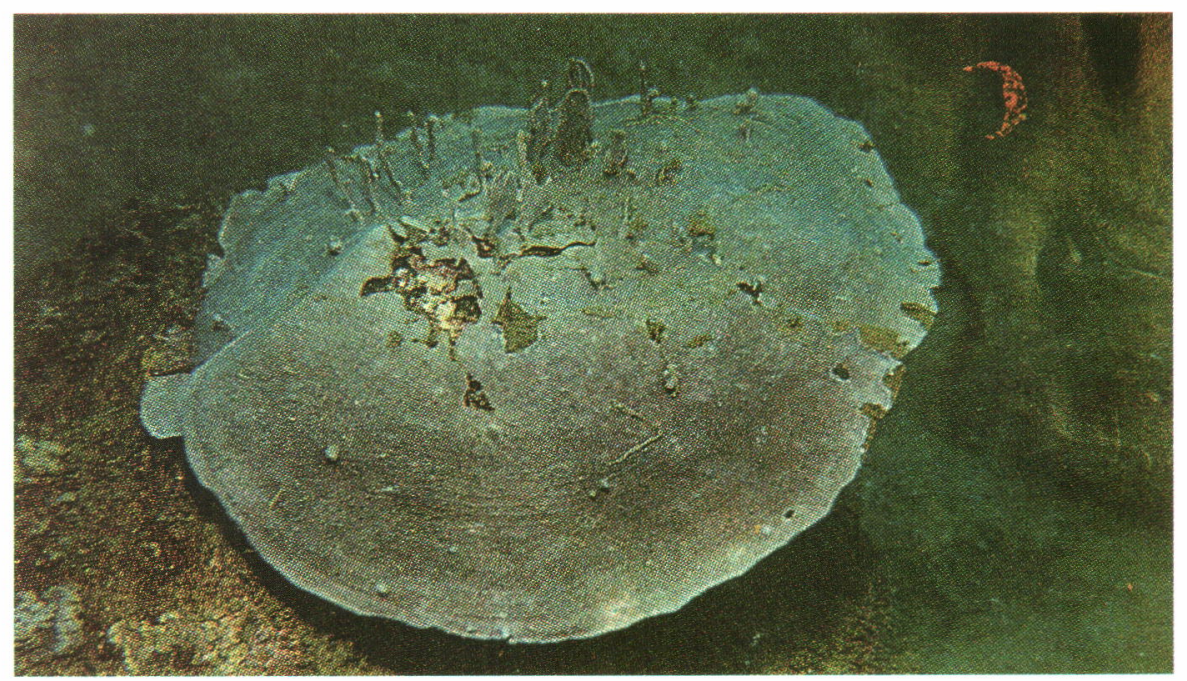

Figure 2. Halichondrida cartilagena

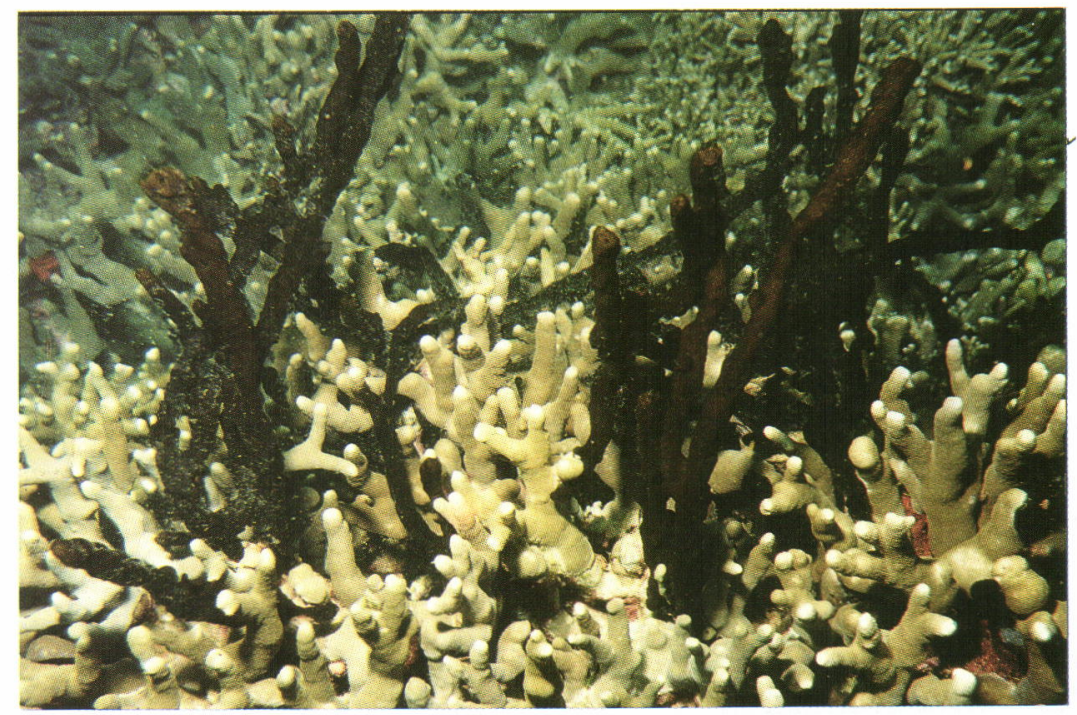

Figure 3. Callyspongia pseudoreticulata 


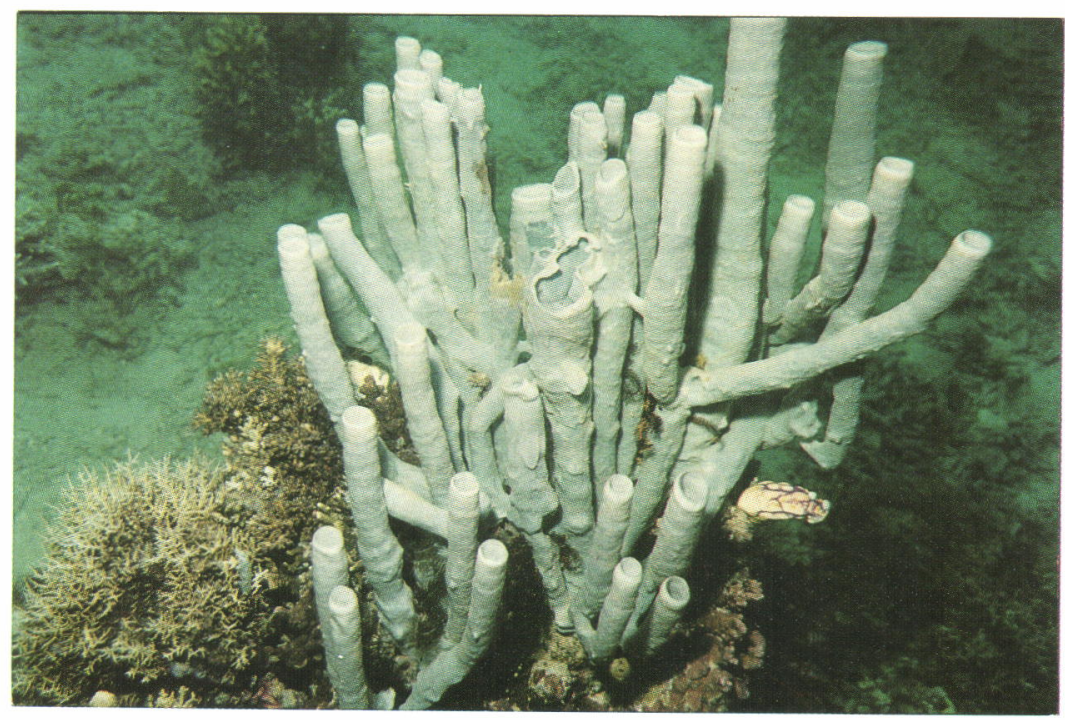

Figure 4. Auletta spp.

Fractionation of the 3 species of sponges based on their polarity and solubility produces 4 fractions, i.e., hexane, neutral ethyl acetate, acid ethyl acetate, and water fraction. For $H$. cartilagena, the water fraction is the only one active in inhibiting the growth of Vibrio spp. (Table 2). The purity of bioactive substances contained in the water fraction increases its inhibition capability.

Table 2. The capability of bioactive extracts from $H$. cartilagena to inhibit growth of Vibrio spp.

\begin{tabular}{lc}
\hline \multicolumn{1}{c}{ Active fraction } & Inhibition zone (mm) \\
\hline Crude extract & $20.3-29.4$ \\
Hexane fraction & $(-)$ \\
Acid ethyl acetate fraction & $(-)$ \\
Neutral ethyl acetate fraction & $(-)$ \\
Water fraction & $25.6-29.6$ \\
\hline
\end{tabular}

Note: (-) no inhibition 
The water fraction of bioactive extract from Auletta spp. inhibits the growth of Acinetobacter spp. in an inhibition zone range is from 28.3 to 35.0 mm (Table 3). The bioactive extracts from both $H$. certilagena and Auletta spp. are very polar and dissolve completely in water. Among the polar compounds which have the potential to be used as bacteriocides are peptides, glicocides, amines, saponins, and macromolecule carbohydrates (Harborne 1973).

Table 3. Inhibition capability of bioactive extracts from Auletta spp. toward the growth of Acinetobacter spp.

\begin{tabular}{lc}
\hline \multicolumn{1}{c}{ Active fraction } & Inhibition zone (mm) \\
\hline Crude extract & $20.3-29.4$ \\
Hexane fraction & $(-)$ \\
Acid ethyl acetate fraction & $(-)$ \\
Neutral ethyl acetate fraction & $(-)$ \\
Water fraction & $25.6-29.6$ \\
\hline
\end{tabular}

Note: (-) no inhibition

C. pseudoreticulata differs from $H$. certilagena and Auletta spp. and produces semipolar bioactive dissolved in ethyl acetate. The acid and neutral ethyl acetate fraction of the inhibits growth of Aeromonas spp., Pseudomonas spp., and Enterobacteriaceae. The largest inhibition zone was produced by the neutral ethyl acetate fraction toward Enterobacteriaceae $(34.0-43.0 \mathrm{~mm})$ followed by acid ethyl acetate fraction toward Pseudomonas spp. (Table 4). For Aeromonas spp., neutral ethyl acetate fraction is more effective than does acid ethyl acetate fraction.

Table 4. Inhibition zone ( $\mathrm{mm}$ ) of bioactive extracts from C.pseudoreticulata toward the growth of bacteria.

\begin{tabular}{lc}
\hline \multicolumn{1}{c}{ Active fraction } & Inhibition zone (mm) \\
\hline Crude extract & $28.1-29.4$ \\
Hexane fraction & $(-)$ \\
Acid ethyl acetate fraction & $(-)$ \\
Neutral ethyl acetate fraction & $(-)$ \\
Water fraction & $28.3-35.0$ \\
\hline
\end{tabular}

Note: (-) no inhibition 
Chemical compounds dissolved in neutral ethyl acetate are neutral, just like alkaloid compounds such as terpenes, triterpenes, policetida, ketosteroids, and squalene derivates. Acidity compounds dissolved in acid ethyl acetate are acidic, e.g. phenolic acid, carboxylic acid, flavonoids, phenyl propanoids, antocyanins and their derivates (Horborne 1973).

Bacteriocides inhibits growth of bacteria through cell wall irritation, protein coagulation due to $\mathrm{pH}$ difference, and hydrolysis and diffusion of cell plasm resulting from osmotic presure imbalance (Salle 1961). Among chemical compounds, peptides, glycocides, terpenoids, steroids, saponins, alkaloids, phenolic acid, alcohol, amines, and organic compound containing metal have the capability to inhibit the growth of bacteria (Salle 1961). Antibiotics and chemical substant such as oxytetracycline, chloramphenicol, malachite green, and prefuran are less effective bacteriocides in fish culture than bioactive sponges (Table 5). At its allowable maximum concentration oxytetracyclin is only capable producing an inhibitation zone of $22.9 \mathrm{~mm}$ for Vibrio spp. and $19.0 \mathrm{~mm}$ for Enterobacteriaceae (Madeali 1995). Chloramphenicol could only inhibit the growth of Vibrio spp. and Enterobacteriaceae at 24.6 and $11.9 \mathrm{~mm}$, respectively (Madeali 1994). Malachite green and prefuran at their maximum allowable concentrations are completely ineffective for either Vibrio spp. or Enterobacteriaceae.

Table 5. Inhibition capability $(\mathrm{mm})$ of bioactive sponge extracts and antibiotics toward Vibrio spp. and Enterobacteriaceae

\begin{tabular}{lcc}
\hline \multicolumn{1}{c}{ Chemical compound } & \multicolumn{2}{c}{ Bacteria } \\
\cline { 2 - 3 } & Vibrio spp. & Enterobacteriaceac \\
\hline H.certilagena bioactive $(20 \mathrm{ppm})$ & 29.6 & - \\
Auletta spp. bioactive $(20 \mathrm{ppm})$ & 35.0 & - \\
C.pseudoreticulata $\mathrm{spp}$. & & 43.0 \\
$\quad$ bioactive $(20 \mathrm{ppm})$ & - & 19.0 \\
Oxytetracycline, $(100 \mathrm{ppm})$ & 22.9 & 11.9 \\
Chloramphenicol, $(100 \mathrm{ppm})$ & 24.6 & - \\
Malachite green, $(100 \mathrm{ppm})$ & - & - \\
Prefuran $(100 \mathrm{ppm})$ & - & \\
\hline
\end{tabular}

Note: (-) no inhibition

Bioactive sponge extracts is suspected of containing peptide, terpenoid, glycocide, saponin, steroid, amine, phenolic acid and squalene and its derivate produced from secondary metabolism. In nature, sponges utilize bacteria as the source of nutrients (Buss 1976), and formbioactive material during synthetise the digestion process. Barnes (1990) reported that sponges are able to filter the 
surrounding bacteria and $77 \%$ of its ommision are enzymatically digested. Specific feeding habits of sponges are suspected to effect the bioactive properties which is a used in digestion process. Consequently sponge bioactive is only affective to restrain the growth of bacteria which is part of sponges main diet. In the others words, bioactive sponge extracts provide a species specific bacteriocides.

\section{Conclusion}

Two ( $H$. certilagena and Auletta spp.) out of three sponges examines for bacteriocides produced specific species bioactive substances and the other one (C. pseudoreticulata) has the potentiality to produce bioactive substances which effective in restrain the growth of 3 species of bacteria, i.e., Aeromonas spp., Enterobacteriaceae, and Pseudomonas spp. The species specific bioactives extracts are mostly polar. The non specific species bioactive extracts are semipolar i.e. dissolved in neutral ethyl acetate. Regardless of the species specific property, bioactive sponge extracts are potentially more effective than do antibiotics for fish health management purposes.

\section{References}

Atmomarono, M., M.I. Madeali, Muliani, dan A. Tompo. 1994. Kasus penyakit udang windu di Kabupaten Pinrang. In Hanafi A., M.Atmomarsono, dan S.Ismawati (Eds.), Prosiding Seminar Hasil Penelitian Perikanan Budidaya Pantai, Maros, 16-19 Juli 1993. p. 35-40.

Barnes, R.D. 1990. Invertebrate zoology. Fourth Ed. Holt-Saunders International Edition.

Brown, J.H. 1989. Antibiotics their use and abuse in aquaculture. Aquaculture 20(2): 34-43.

Brusca, R.C. and G.J. Brusca. 1990. Invertebrates. Sinaeur Associbated, Inc., Mass. USA. $922 \mathrm{p}$.

Buss, L.W. 1976. Better living through chemistry: The realtionship between allelochemical interactions and competitive Networks. In Harriso, F.W. and R.R. Cowde (Eds.), Aspects of sponge biology. Academic Press. New York. p. 315-27.

Cimminielo, P., F. Ernesto, M. Silvana, and M. Alvinso. 1989. A Novel conyugated ketosteroid from the marine sponge Dyctionella incisa. J. of Natural Product, 52(6): 1331-33.

Crispino, A., Deguillo, S. De Rosa, and G. Strazullo. 1989. A New Bioactive Derivation of ovarol from the marine sponge Dysidea avara. J. of Natural Product, 52(6): 646-48. 
Cowan, S.T. 1985. Manual for the identification of medical bacteria. Cambridge University Press. Cambridge.

Gunasekara, S.P., S. Cramck, and R. Longlei. 1989. Immunosuppresive compounds from a deep water marine sponge, Agelas flabelliformis. J. of Natural Product, 52(4): 754-61.

Hadiman. 1982. Zat bioactive ex tanaman untuk kesejahtaraan manusia. Bahan seminar intern Lab Kimia Tanaman. UNPAD. unpbulished.

Harborne, J.D. 1973. Phytochemical Methods. Chapman and Hill. London.

Karuso, P., C.R. Cambic, and B.F. Boeden. 1989. Chemistry of sponges VI Scalarane sestesterpenes from Hyatella intestinalis. J. of Natural Product, 52(2): 289-93.

Madeali, M.I. 1995. Toleransi bakteri terhadap antibiotik. Laporan Hasil Penelitian. Balai Penelitian Perikanan Pantai, Maros.

Madeali, M.I., M. Atmomarono, A. Tompo, dan Muliani. 1994. Studi kasus penyebab kematian udang windu, Penaeus monodon di tambak intensif. J. Penelitian Budidaya Pantai, 9(4): 23-28.

Madaio, A., V. Picciali, and D. Sica. 1989. New Polyhydroxysterols from the Dictyoceratid sponges Hippospongia comunnis Spongianella gracillis. J. Natural Product, 52(5): 952-61.

Rukyani, A. 1993. Penanggulangan penyakit udang windu, Penaeus monodon. In Hanafi, A., M. Atmomarsono, dan S. Ismawati (Eds.), Prosiding Seminar Hasil Penelitian Perikanan Budidaya Pantai, Maros, 16-19 Juli 1993. p. 1-8.

Salle, A.J. 1961. Fundamental Principles of Bacteriology. McGraw. Hill Book Company Inc., London 479.

Suryati, E. 1993. Isolasi bahan aktif Isotoma longiflora terhadap bakteri Aeromonas spp. pada ikan. Symposium Perikanan Indonesia I. Jakarta.

Suryati, E. dan Y. Hala. 1993. Bioactivitas Isotoma longiflora terhadap bakteri Pseudomonas spp. pada ikan. Seminar Ilmiah Peringatan 30 Tahun FMIPA Universitas Hasanuddin. Ujung Pandang. 